\title{
ASSESSMENT OF FINANCIAL BENEFITS OF SELECTED MEZZANINE FINANCING INSTRUMENTS
}

\author{
Libena Tetrevova ${ }^{1}$, Jan Svedik ${ }^{2}$ \\ Department of Economy and Management of Chemical and Food Industries, Faculty of Chemical Technology, \\ University of Pardubice, Studentska 95, 53210 Pardubice, Czech Republic \\ E-mails: 'libena.tetrevova@upce.cz (corresponding author); ${ }^{2} j a n . s v e d i k @ u p c e . c z$
}

\begin{abstract}
The paper deals with the problems of assessment of financial benefits of subordinated loans and convertible bonds. The paper authors aim to propose and verify methodology for assessment of the financial benefits of subordinated loans and convertible bonds. The introductory part characterizes the theoretical background of assessment of the financial benefits of the classic financing sources. Subsequently, the authors propose methodology for assessment of the financial benefits of subordinated loans and convertible bonds. The final part includes a case study that, using the proposed methodology, documents the outcomes of the comparison of the financial benefits of the mentioned instruments in the actual conditions of the Czech Republic.
\end{abstract}

Keywords: financial sources, mezzanine instruments, subordinated loans, convertible bonds, assessment of financial benefits, cost intensity of mezzanine financing instruments.

JEL Classification: C51; G10; G32.

\section{Introduction}

Utilization of unconventional economic tools, procedures, and practices in all areas of corporate activity (in the context of quantitative methods (Vlckova et al. 2012)) is a prerequisite for prosperity and future existence of businesses in the present turbulent environment. These tools, procedures, and practices can, on the one hand, represent an interesting opportunity for businesses, but they might, on the other hand, also become a significant threat. From the point of view of corporate financing, innovated tools also include mezzanine financing instruments. Although some mezzanine financing instruments were first used in the USA as early as in the 80's of the 20th century and in Europe in the 90 's, they still are not very widely used in a number of countries.

Mezzanine financing (or just mezzanine) represents a hybrid form of financing, which combines the features of equity and debts (Anson et al. 2010; Silbernagel, Vaitkunas 2010; Welz 2006). From the point of view of the corporate balance, it is possible to distinguish equity mezzanine (mezzanine financing with a higher rate of equity) and debt mezzanine (mezzanine financing with a higher debt tendency) (Meluzin, Zinecker 2009; Volkmann et al. 2010). From the point of view of public tradability, it is possible to distinguish private mezzanine (it includes mezzanine instruments that do not enter the open capital market) and public mezzanine (it includes mezzanine instruments that are publicly tradable on the capital market) (Baker, Filbeck 2013; European Commission 2010; Vasilescu, Popa 2006). Equity mezzanine instruments can include silent partnerships and preferred stocks, which belong, in the corporate financial structure, to the equity, but they limit one or more of the basic ownership rights, such as e.g. the right to participate in the management of the company. Debt mezzanine instruments can include participating loans and bonds, subordinated loans and bonds, convertible bonds exchangeable for stocks and bonds with warrants, which belong, from the point of view of the balance, to the debt capital, but they are connected with the right or obligation of the equity provider. As for participating debts, the yield depends on the achieved corporate profits, just as it is with the owners' yield. The liabilities connected with subordinated debts, just as the liabilities towards the owners, are not settled until all the liabilities towards the other creditors have been settled. Convertible bonds provide, under certain conditions, the possibility of exchanging the bond for the issuer's stocks, and bonds with warrants are connected with the right to buy the issuer's stocks, and so the investor can become an owner of a part of the company. Private mezzanine financing instruments include silent partnerships, participating loans, and subordinated loans. On the other hand, public mezzanine financing instruments include preferred stocks, participating bonds, subordinated bonds, 
convertible bonds, and bonds with warrants. (Meluzin, Zinecker 2009; Svedik, Tetrevova 2015; Tetrevova 2009)

Each of the mezzanine financing instruments is characterized by specific features that determine its advantages and disadvantages financial managers have to take into account when considering their incorporation into the corporate capital structure; see more in (Svedik, Tetrevova 2014). Apart from these qualitative criteria, it is also necessary to consider quantitative criteria and to assess the financial demands of individual capital forms. The financial theory offers several possibilities of assessment for the classic financial instruments, both in the form of the cost intensity of individual types of capital based on the method of the weighted average cost of capital, and the criteria of financing effectiveness in the form of the net present value of capital or the internal rate of return on capital. Therefore, it is possible to ask a research question whether it is possible to use the procedures of assessment of the financial demands of acquisition and holding of a financial source used for the classic financial instruments also for mezzanine instruments. In view of the specific characteristics of mezzanine instruments, we can assume that it will be necessary to modify the given tools and procedures. We can formulate the following hypothesis: Assessment of the financial benefits of mezzanine financing sources requires modification of the assessment procedures used for the classic financing sources. With respect to the European tradition of debt financing (Hobza 2009; Hucka et al. 2011) and to the fact that a significant alternative to bank loans is represented by corporate bonds (both from the point of view of the corporate practice, and e.g. from the point of view of the pecking order theory), the attention will be focussed on assessment of selected debt mezzanine instruments, i.e. mezzanine financing instruments with a higher debt tendency. Specifically, they will include subordinated loans and convertible bonds, as only these two instruments were, in the Czech Republic in the monitored period of 2006-2012, used by non-financial enterprises, whose core business consists in manufacturing and providing non-financial services (Eurostat 2010). The authors of this paper aim to propose and verify methodology for assessment of the financial benefits of subordinated loans and convertible bonds.

\section{Data and methodology}

The paper is based on integration of two key areas of knowledge, the theory and practice of financial management. The starting point was a secondary analysis aiming to process the current status of knowledge of the solved problems, whose essence was research into the domestic and foreign professional literature.

The second phase included qualitative research focussing on identification of the structure and volume of the cost items of bank loans and corporate bonds in classic and mezzanine forms. As for determination of the costs of bank loans, the research was performed in the form of directed interviews with representatives of banks belonging, in accordance with the methodology of the Czech National Bank (CNB) among large banks, i.e. banks with the balance sum exceeding CZK250bn (CNB 2013), i.e. with representatives of Ceskoslovenska obchodni banka, Ceska sporitelna, Komercni banka, and Unicredit bank on the one hand and, on the other hand, with a representative of the Czech-Moravian Guarantee and Development Bank (CMGDB), which was, in the monitored period (2006-2012), the only provider of subordinated loans in the Czech Republic, and also with a representative of Broker Trust, a company dealing with financial consultancy and mediation of financial trade in the Czech Republic. As for determination of the costs of corporate bonds, the research was in the form of directed interviews with representatives of Ceska sporitelna and WOOD \& Company. These directed interviews were conducted in June - September 2013 and were 50 minutes long on average.

The findings obtained through the research into the professional literature and the information obtained through the directed interviews were used to propose methodology for assessment of the financial benefits on the principle of the cost intensity for subordinated loans and convertible bonds. Subsequently, the proposed methodology was verified with a case study presenting outcomes of comparison of the financial benefits of subordinated loans and convertible bonds in the actual conditions of the Czech Republic.

\section{Theoretical background of assessment of the financial benefits of financing sources}

The professional literature offers two basic ways of assessment of the financial benefits of financing sources, which are specified for the classic financing sources, i.e. assessment on the basis of comparison of the cost of capital, and on the basis of the financing effectiveness criteria in the form of the internal rate of return on capital and the net present value of capital.

The basic way of quantification of the cost of capital can be seen in determination of the cost of 
individual types of capital within the method of the weighted average cost of capital (WACC); see more e.g. in (Baker, Martin 2011; Kislingerova et al. 2007; Pratt, Grabowski 2014; Vochozka 2011). This method specifies the cost of individual types of capital like payments the company has to make in relation to obtaining the appropriate types of capital. The cost of individual types of capital is expressed as a percentage rate, and so it is possible to compare them. A shortcoming of this way of cost determination is the fact that it considers as the cost of debt only the interest, or the issuance costs in the case of corporate bonds. The other costs that can be connected with acquisition of debt capital, e.g. fees relating to loans, or the costs incurred within the life cycle of the bond issue, are not taken into account when calculating the cost of debt within the method of WACC. Another significant disadvantage can be seen in the fact that formulas in this basic form, specified in the professional literature, cannot be used in financial instruments where the yield for the creditor is not specified in the form of interest, such as e.g. in participating loans or participating bonds.

An alternative possibility of assessment of the financial benefits of financing sources is assessment through the internal rate of return on capital, which ranks among the financing effectiveness criteria (Tetrevova 2006). The internal rate of return on capital represents an analogue of the internal rate of return used for assessment of investments. This method monitors incomes and expenses relating to individual types of capital. The internal rate of return on capital then represents a discount rate, where the difference between the present value of all the future incomes and the present value of all the future expenses equals zero (Fotr, Soucek 2011). However, the internal rate of return on capital is not of the universal character either, and it is not possible to use it for determination of the cost of debt in all types of bonds. The thing is that in the case of convertible bonds the internal rate of return on capital reaches, when the conversion rights are exercised, negative values from a certain volume of conversion, which does not, from the point of view of the information value of calculation of the cost of capital, make sense.

Another possible way of assessing the financial benefits of selected types of capital is through the net present value of capital, which also represents a criterion of the effectiveness of financing (Oswald 1994). This criterion is based on comparison of the present value of cash incomes and the present value of cash expenses connected with the acquired type of capital. The resulting values are expressed as monetary sums, where the financing option with a higher net present value of capital is more advantageous. Therefore, the net present value of capital is based on the same principle as the net present value used for assessment of investments. The only significant difference between the net present value of capital and the net present value used for making investment decisions is the fact that the first cash flow is positive, while the subsequent flows are negative. The professional literature solves assessment of the financing effectiveness through the net present value of capital only from the general point of view, but not from the point of view of mezzanine financing instruments. Moreover, application of this criterion is complicated by a number of limiting factors, e.g. comparison must be based on a comparable value of instruments, or it is necessary to compare instruments with the same lifetime period. The net present value of capital, just as the internal rate of return on capital, then cannot be used as a criterion of assessment of convertible bonds in the case of exercise of conversion rights as it would not be possible, in consequence of non-redemption of the principal of these bonds, to compare the resulting values of this indicator with values achieved in other types of financial instruments.

\section{Proposed methodology for assessment of the financial benefits of subordinated loans and convertible bonds}

The methods of assessment of the financial benefits of financing sources specified in the literature are, as the above mentioned shows, connected with a number of problems, and they are not entirely suitable for assessment of the financial benefits of mezzanine financing instruments. Therefore, the hypothesis that assessment of the financial benefits of mezzanine financing sources requires modifycation of the assessment procedures used for the classic financing sources has been proven. For this reason, this paper hereafter proposes a procedure for assessment of the financial benefits of selected mezzanine financing instruments, i.e. subordinated loans and convertible bonds, which were the only debt mezzanine instruments used by non-financial companies in the Czech Republic in the monitored period. Moreover, a convertible bond is an instrument that is connected with the highest number of restrictions from the point of view of application of the methods of assessment of the financial benefits specified in the professional literature. The proposed method of assessment of the financial benefits of the above mezzanine financing instruments is based on the principle of cost intensity, where it is abstracted from expenses that are not costs, and from incomes 
of individual forms of capital, taking the factor of time value of money into account at the same time.

Quantification of the cost of debt acquired by acceptance of a subordinated bank loan is affected by a lot of factors. The factors affecting the costs, such as the interest rate, fees connected with the bank loan in relation to its acquisition and within the course of its lifetime, or its maturity, also have to include the frequency of interest calculation or the way of repayment, which influence the costs, too. If we work on the assumption that the repayment is even, i.e. the method where the company is repaying the principal of the loan evenly distributed into individual instalments, and also the fact that the company also has to pay, apart from the interest, the bank loan acquisition costs $\left(\mathrm{C}_{\mathrm{abl}}\right)$ and other bank loan life cycle costs $\left(\mathrm{C}_{\mathrm{lcbl}, \mathrm{t}}\right)$, it is then possible to propose, for calculation of the cost of debt acquired through a subordinated bank loan, a simplified formula, which is also usable for calculation of the cost of the classic bank loan, as follows:

$$
\begin{aligned}
& C_{B L}=C_{a b l}(1-T)+ \\
& \sum_{t=1}^{n}\left[\frac{\left(P_{b l}-\frac{P_{b l}}{n}(t-1)\right) i_{b l, t}(1-T)+C_{l c b l, t}(1-T)}{\left(1+r_{d}\right)^{t}}\right],
\end{aligned}
$$

where: $C_{a b l}$ - bank loan acquisition costs in $\mathrm{CZK}$; $\mathrm{C}_{\mathrm{BL}}$ - bank loan costs (after tax) in CZK; $C_{l c b l, t}-$ other bank loan life cycle costs within individual periods $(\mathrm{t})$ in $\mathrm{CZK}$; $i_{b l, t}$ - bank loan interest rate in individual periods $(\mathrm{t})$ expressed as a coefficient (i.e. $\% / 100) ; n$ - number of periods until debt maturity; $\mathrm{P}_{\mathrm{bl}}$ - bank loan principal in CZK; $r_{d}$ - discount rate expressed as a coefficient (i.e. \%/100); $t$-individual periods (yearly, quarterly, monthly, etc.) until debt maturity; $T-$ tax coefficient (profit tax rate in $\% / 100)$.

The cost of debt in the form of corporate bonds convertible for stocks can be determined in a similar way. At the same time, we particularly have to take account of the costs relating to the process of issuance of corporate bonds $\left(\mathrm{C}_{\mathrm{ib}}\right)$, the paid interest $\left(\mathrm{I}_{\mathrm{b}, \mathrm{t}}\right)$, which is usually determined from the bond nominal value $\left(\mathrm{NV}_{\mathrm{b}}\right)$ and the interest rate $\left(\mathrm{i}_{\mathrm{b}, \mathrm{t}}\right)$, and also the other bond issue life cycle costs $\left(\mathrm{C}_{\mathrm{lcb}, t}\right)$, and also any potential costs of conversion of bonds into stocks $\left(C_{c}\right)$. On the basis of these facts, we suggest using the following formula for calculation of the cost of debt acquired through a convertible bond issue:

$$
\begin{aligned}
& C_{C B}=C_{i b}(1-T)+ \\
& \sum_{t=1}^{n}\left[\frac{N V_{b} \cdot i_{b, t}(1-T)+C_{l c b, t}(1-T)}{\left(1+r_{d}\right)^{t}}\right]+\frac{C_{c}}{\left(1+r_{d}\right)^{n}},
\end{aligned}
$$

where: $C_{c}-$ costs of conversion of bonds into stocks in $\mathrm{CZK} ; C_{C B}$ - convertible bond costs (after tax) in $\mathrm{CZK} ; C_{i b}$-bond issuance costs in $\mathrm{CZK} ; C_{l c b, t}-$ other bond issue life cycle costs within individual periods (t) in CZK; $i_{b, t}$ - bond interest rate in individual periods (t) expressed as a coefficient (i.e. \%/100); $N V_{b}$ - bond nominal value in CZK; other used symbols, see above.

It is necessary to add to Formula (2) that it only quantifies the costs directly relating to the given bond. However, in the event of exercise of the right of conversion into stocks, these stocks are connected with occurrence of additional payments, e.g. payment of dividends. Furthermore, there might be some more effects that can hardly be quantified, such as a change in the corporate ownership structure, and so also the possibility of participating in the management of the given company.

\section{Case study - comparison of the costs of subordinated loans and convertible bonds}

The below specified comparison is based on actual data obtained within a survey performed among representatives of banking entities and financial companies in the Czech Republic. As for subordinated loans, the comparison involved a subordinated loan with which companies were provided in 2006-2012 by CMGDB within a programme called "Progress". It was a type of a long-term special loan with a fixed interest rate of $3 \%$ p.a., provided in the volume of CZK2 - $25 \mathrm{~m}$, which had to be from at least 50\% co-financed through a loan from a commercial bank; see more in (CMGDB 2007). The convertible bonds chosen for the comparison included convertible bonds of Orrero, a.s., issued in 2011, due to the fact that it is the most current issue of convertible bonds in the Czech Republic. They were paper bearer bonds convertible into common stocks, issued with the nominal value of CZK5000 in the total volume of CZK $26.24 \mathrm{~m}$ (i.e. 5248 pieces of bonds) with a two-year maturity date, whose yield was determined as the average CNB Lombard rate for the previous 12 months $+2.5 \%$ p.a. There was no exercise of the conversion right in this particular issue of convertible bonds, and so the calculation will be based, for one thing, on this actual situation, and for another on a model situation - including conversion.

The comparison will be based on a single volume of debt, derived from the volume of the issue 
of the above convertible bonds (CZK26.24m), and with respect to the conditions of the programme "Progress", regarding the volume and share of the subordinated loan, we will be considering a subordinated loan of CZK11.24m in combination with a classic bank loan (mediated by Broker Trust) of CZK15m, with a two-year maturity date (the same as in the case of the above convertible bonds) and an interest rate of $6.8 \%$ p.a.

In view of the fact that some partial costs of loans and convertible bonds (in the case of acquisition costs $-\mathrm{C}_{\mathrm{ab}} / \mathrm{C}_{\mathrm{ib}}$ and other life cycle costs $\mathrm{C}_{\text {lcbl, },} \mathrm{C}_{\mathrm{lcb}, \mathrm{t}}$ ) were identified with individual representatives of the banking entities and financial companies in a range, the costs of individual instruments will be specified in intervals. These intervals will then determine the minimum and maximum expected costs of the analysed financial sources $\left(\mathrm{C}_{\mathrm{BL}} / \mathrm{C}_{\mathrm{CB}}\right)$.

To determine the costs of a combined loan of CZK26.24m with a two-year maturity date, it is possible to use Formula (1), which calculates the costs of the bank loan from the bank loan acquisition costs $\left(\mathrm{C}_{\mathrm{abl}}\right)$, the interest $\left(\mathrm{I}_{\mathrm{bl}, \mathrm{t}}\right)$, and the other bank loan life cycle costs $\left(\mathrm{C}_{\text {lcbl,t }}\right)$.

The bank loan acquisition costs $\left(\mathrm{C}_{\mathrm{abl}}\right)$ equalled, in the analysed classic loan, zero, and in the subordinated loan they only consisted of a fee for consultation required by the client for assessment of the feasibility of the business plan before entering into the contractual relations, which was CZK500 for each commenced hour. This consultation will be included in the calculation in the estimated duration of 2 to 4 hours. The considered bank loan acquisition costs $\left(\mathrm{C}_{\mathrm{abl}}\right)$ will then amount to CZK1000 2000. The income tax rate of legal entities in the monitored period was $19 \%$.

Other constituent parts of Formula (1) are interests on the bank loan in individual years $\left(\mathrm{I}_{\mathrm{bl}, \mathrm{t}}\right)$. When determining the interest $\left(\mathrm{I}_{\mathrm{bl}, \mathrm{t}}\right)$, where we assume that they were paid once a year, we will be considering a fixed interest rate of a classic bank loan $\left(\mathrm{i}_{\text {cbl, }}\right)$ of $6.8 \%$ and a fixed subordinated loan interest rate $\left(i_{s, t, t}\right)$ of $3 \%$. The interest rate of the concerned combined loan $\left(\mathrm{i}_{\mathrm{cl}, \mathrm{t}}\right)$ was $5.2 \%$ (in Formula (1) as $\left.i_{b l, t}\right)$, and it was determined on the basis of the following formula:

$$
i_{c l, t}=\left[\left(\frac{T V_{C B L}}{T V_{C L}} * i_{c b l, t}\right)+\left(\frac{T V_{S L}}{T V_{C L}} * i_{s l, t}\right)\right],
$$

where: $i_{c b l, t}$ - classic bank loan interest rate in individual periods $\mathrm{t}$ expressed as a coefficient (i.e. $\% / 100) ; i_{c l, t}$ - combined loan interest rate in individual periods $t$ expressed as a coefficient (i.e. \%/100); $i_{s l, t}$ - subordinated loan interest rate in individual periods $\mathrm{t}$ expressed as a coefficient (i.e. \%/100); $T V_{C B L}$ - total volume of the classic bank loan in $\mathrm{CZK} ; T V_{C L}$ - total volume of the combined loan in $\mathrm{CZK} ; T V_{S L}$ - total volume of the subordinated loan in $\mathrm{CZK}$.

Another constituent part of Formula (1) is the other bank loan life cycle costs $\left(\mathrm{C}_{\text {lcbl,t }}\right)$. These costs amounted, in the given type of a classic bank loan, to CZK300 - 400 per month, while in the given subordinated loan they equalled zero. I.e. the yearly volume of the other combined loan life cycle costs was between CZK3600 and CZK4800.

Formula (1) also includes a discount rate $\left(r_{d}\right)$. The discount rate $\left(r_{d}\right)$ represents the annual rate of inflation in the Czech Republic, and to avoid its extreme values in the monitored period, we will base our calculation on the CNB inflation target, which has been $2 \%$ since 2010 (CNB 2010).

If we substitute the above values in Formula (1), we get the cost of debt acquired through the combined loan, in the interval from CZK1,612,760 to $1,615,647$.

At the same time, it is also possible to quantify and compare the share of individual cost items. 99.41 to $99.59 \%$ of the cost of debt acquired through a combined loan is made up of the interest on this loan $\left(\mathrm{I}_{\mathrm{bl}, \mathrm{t}}\right)$. The other bank loan life cycle costs $\left(\mathrm{C}_{\text {lcbl, }}\right)$ amounting to $0.35-0.47 \%$ and the acquisition costs of this loan $\left(\mathrm{C}_{\mathrm{abl}}\right)$ of $0.06-0.12 \%$ constitute almost a negligible part.

To determine the cost of convertible bonds $\left(\mathrm{C}_{\mathrm{CB}}\right)$ of the nominal value $\left(\mathrm{NV}_{\mathrm{b}}\right)$ of $\mathrm{CZK} 26.24 \mathrm{~m}$ with a two-year maturity date issued by the company Orrero, a.s., in 2011, we will use Formula (2), which includes the issuance costs $\left(\mathrm{C}_{\mathrm{ib}}\right)$, the interest $\left(\mathrm{I}_{\mathrm{b}, \mathrm{t}}\right)$, the other bond issue life cycle costs $\left(\mathrm{C}_{\mathrm{lcb}, \mathrm{t}}\right)$, and the cost of conversion of bonds into stocks $\left(\mathrm{C}_{\mathrm{c}}\right)$. In view of the fact that the amount of the above types of costs, with the exception of the cost of conversion of bonds into stocks $\left(\mathrm{C}_{\mathrm{c}}\right)$, will be the same both in the actual, and in the model situation (Alternative 1 - without conversion, Alternative 2 - with conversion), they will be specified for both alternatives together. What will only be presented separately will be the cost of conversion of bonds into stocks $\left(\mathrm{C}_{\mathrm{c}(1)}\right.$ and $\left.\mathrm{C}_{\mathrm{c}(2)}\right)$ and the total cost of convertible bonds $\left(\mathrm{C}_{\mathrm{CB}(1)}\right.$ and $\left.\mathrm{C}_{\mathrm{CB}(2)}\right)$.

The convertible bond issuance costs $\left(\mathrm{C}_{\mathrm{ib}(1)}\right.$ and $\mathrm{C}_{\mathrm{ib}(2)}$ ) will be determined on the basis of the information obtained from the representatives of Ceska sporitelna and WOOD \& Company, and on the basis of the rate book of the Central Securities Depository Prague (Central Securities Depository Prague 2013). These costs are given by the sum of a fee paid to the issue manager for preparation and subscription of 
the issue ( $1-2 \%$ of the nominal value of the issue), a fee for registration of new bonds (given by the formula: $(0.00005+\mathrm{k} 2 * \mathrm{M}) * \mathrm{O}$, where $\mathrm{O}$ is the nominal value of the volume of securities, $M$ is the number of months to maturity, and $\mathrm{k} 2$ is a coefficient which is based on the maturity date of the bonds, and in this case it is 0.0000035 ), a fee for assignment of the International Securities Identification Number ISIN (CZK580), and the cost of print of the bonds (CZK10 - 200 per bond). As for the legal person income tax rate, it amounted to $19 \%$ in the monitored period. Individual items of the issuance costs of convertible bonds $\left(\mathrm{C}_{\mathrm{ib}(1)}\right.$ and $\left.\mathrm{C}_{\mathrm{ib}(2)}\right)$ will thus be assumed as follows: the fee paid to the issue manager for preparation and subscription of the issue CZK262,400 - CZK524,800, the fee for registration of new bonds CZK3516, the fee for assignment of ISIN CZK580, and the cost of print of the bonds CZK52,480 - CZK1,049,600.

Another constituent part of Formula (2) is represented by the interest on bonds in individual years $\left(\mathrm{I}_{\mathrm{b}(1), t}\right.$ and $\left.\mathrm{I}_{\mathrm{b}(2), t}\right)$. Orrero, a.s. paid the interest within the given issue of convertible bonds biannually. Calculation of the interest $\left(\mathrm{I}_{\mathrm{b}, \mathrm{t}}\right)$ was based on the convention for calculation of interest BCK Standard $30 \mathrm{E} / 360$. The interest rate $\left(\mathrm{i}_{b, t}\right)$ in this issue of convertible bonds was $2.5 \%$, plus the average CNB Lombard rate for the previous 12 months. On the basis of these figures, it is possible to determine the interest on this issue of convertible bonds for individual periods $\left(\mathrm{I}_{\mathrm{b}(1), \mathrm{t}}\right.$ and $\left.\mathrm{I}_{\mathrm{b}(2), t}\right)$; see more in Table 1 .

The other bond issue life cycle costs $\left(\mathrm{C}_{\mathrm{lcb}(1), \mathrm{t}}\right.$ and $\mathrm{C}_{\mathrm{lcb}(2), \mathrm{t}}$ ) consisted of fees connected with payment of the interest and the principal. These fees amounted to CZK3000 + CZK5 for each investor. We will assume these fees, and so also the other convertible bond life cycle costs $\left(\mathrm{C}_{\operatorname{lcb}(1), t}\right.$ and $\mathrm{C}_{\mathrm{lcb}(2), \mathrm{t}}$, at the amount of CZK3005-29,240.

Formula (2) also includes the cost of conversion of bonds into stocks $\left(\mathrm{C}_{\mathrm{c}(1)}\right.$ and $\left.\mathrm{C}_{\mathrm{c}(2)}\right)$. In consideration of the fact that the conversion right was not actually exercised in the analysed issue of convertible bonds (Alternative 1), the cost of conversion $\left(\mathrm{C}_{\mathrm{c}(1)}\right)$ will be equalled to zero in this case. However, the model Alternative 2 presumes that the conversion right was exercised in all the bonds, i.e. an exchange for 5248 pieces of new common stocks of the nominal value of CZK5000/stock. In this case, the conversion costs $\left(\mathrm{C}_{\mathrm{c}(2)}\right)$ will, in accordance with information obtained from the representatives of Ceska sporitelna and WOOD \& Company and the rate book of the Central Securities Depository Prague (Central Securities Depository Prague, 2013), include a fee for an increase in the volume of stocks (the fee is specified on the basis of the following
Table 1. Determination of the interest on convertible bonds issued by Orrero, a.s. for the period from 1 September 2011 to 30 June 2013 (Source: Own processing on the basis of (CNB 2015))

\begin{tabular}{|c|c|c|c|c|c|}
\hline Pay day & 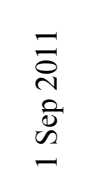 & 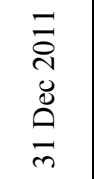 & $\begin{array}{l}\text { Na } \\
\stackrel{\sim}{2} \\
\Xi \\
\Xi \\
0\end{array}$ & 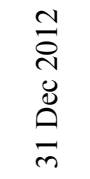 & $\begin{array}{l}m \\
\stackrel{m}{\Xi} \\
\equiv \\
\equiv \\
0\end{array}$ \\
\hline $\begin{array}{l}\text { Number of days for } \\
\text { which interest is paid }\end{array}$ & 75 & 120 & 180 & 180 & 180 \\
\hline $\begin{array}{l}\text { Average CNB Lom- } \\
\text { bard rate for previous } \\
12 \text { months }(\%)\end{array}$ & 1.75 & 1.75 & 1.73 & 1.37 & 0.67 \\
\hline Total interest rate (\%) & 4.25 & 4.25 & 4.23 & 3.87 & 3.17 \\
\hline $\begin{array}{l}\text { Total volume of } \\
\text { interest payments } \\
(\mathrm{CZK})\end{array}$ & 232,3 & 371,7 & 555,1 & 507,1 & 416,3 \\
\hline
\end{tabular}

formula: $0.00068 * \mathrm{O}$, where $\mathrm{O}$ is the nominal value of the newly subscribed issue, but not more than CZK800,000), a fee for securing the priority rights to acquisition of securities (the fee is specified on the basis of the following formula: $0.00068^{*} \mathrm{O}$, where $\mathrm{O}$ is the nominal value of the newly subscribed issue, but not more than CZK50,000), and the cost of print of the issuer's stocks (CZK10 CZK200 for a single stock). Individual items of the cost of conversion of bonds into stocks $\left(\mathrm{C}_{\mathrm{c}(2)}\right)$ will be assumed as follows: a fee for an increase in the volume of stocks of CZK17,843, a fee for securing priority rights to acquisition of securities CZK50,000, the cost of print of new stocks CZK52,480 - CZK1,049,600.

Formula (2) includes a discount rate $\left(r_{d}\right)$. Its calculation in both alternatives will again be based on the CNB inflation target of $2 \%$.

If we substitute the above values in Formula (2), the result in Alternative 1 (without exercise of the conversion right) is in the interval from CZK1,918,424 to CZK3,042,604. The largest share in the cost of convertible bonds $\left(\mathrm{C}_{\mathrm{CB}(1)}\right)$ was, in this case, made up of the interest $\left(\mathrm{I}_{\mathrm{b}(1), t)}\right)$, which accounted for $54.17-85.91 \%$. The share of the issuance costs $\left(\mathrm{C}_{\mathrm{ib}(1)}\right)$ in the cost of convertible bonds $\left(\mathrm{C}_{\mathrm{CB}(1)}\right)$ was between 13.47 and $42.02 \%$. The share of the other life cycle costs $\left(\mathrm{C}_{\mathrm{lcb}(1), \mathrm{t}}\right)$ was almost negligible, amounting only to 0.62 to $3.81 \%$.

If we substitute the above values in Formula (2), the result in Alternative 2 (the conversion right was exercised in all the bonds) is in the interval from CZK2,012,101 to CZK3,912,586. Also in this case, the largest share in the cost of convertible bonds $\left(\mathrm{C}_{\mathrm{CB}(2)}\right)$ was made up of the interest $\left(\mathrm{I}_{\mathrm{b}(2), \mathrm{t}}\right)$, which accounted for $42.12-81.91 \%$. The issuance costs $\left(\mathrm{C}_{\mathrm{ib}(2)}\right)$ accounted, in this case, for $12.84-32.68 \%$. 
The cost of conversion of bonds into stocks $\left(\mathrm{C}_{\mathrm{c}(2)}\right)$ accounted for $4.66-22.24 \%$. The share of the other

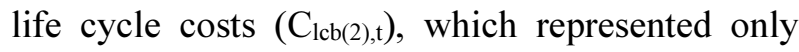
$0.59-2.96 \%$, were again almost negligible.

The above case study implies that the costs of the analysed combined loan were between CZK1,612,760 and CZK1,615,647, the costs of the analysed convertible bonds in Alternative 1 (the conversion rights were not exercised) were between CZK1,918,424 and CZK3,042,604, and the costs of the analysed convertible bonds in Alternative 2 (the conversion rights were exercised) were between CZK2,012,101 and CZK3,912,586. Higher expected costs of debt are thus connected with the analysed convertible bonds in the entire interval of these costs. The above comparison is a proof of the prevailing assertion of the financial theory and practice, see more e.g. in (Valach 2005) or (Tetrevova 2006), that bank loans are connected with lower costs compared to the costs of corporate bonds (with respect to the volume of the issue). As for convertible bonds, the expected costs are logically higher if the conversion rights are exercised, as a result of the cost of conversion of bonds into stocks $\left(\mathrm{C}_{\mathrm{c}(2)}\right)$.

It is also possible to compare both analysed financial instruments from the point of view of their partial cost items. The expected amounts of the partial cost items of both analysed instruments differ significantly. While in the combined loan the interest $\left(\mathrm{I}_{\mathrm{bl}, \mathrm{t}}\right)$ accounts for almost all the expected cost of debt, in convertible bonds it is the interest on convertible bonds $\left(\mathrm{I}_{\mathrm{b}(1), \mathrm{t}}\right.$ and $\left.\mathrm{I}_{\mathrm{b}(2)}\right)$ together with the convertible bond issuance costs $\left(\mathrm{C}_{\mathrm{ib}(1)}\right.$ and $\left.\mathrm{C}_{\mathrm{ib}(2)}\right)$ what accounts for almost all the expected costs. The other life cycle costs $\left(\mathrm{C}_{\mathrm{lcbl}, \mathrm{t}} / \mathrm{C}_{\mathrm{lcb}(1), \mathrm{t}}\right.$ and $\left.\mathrm{C}_{\mathrm{lcb}(2), \mathrm{t}}\right)$ represent almost negligible costs in both of the above instruments.

\section{Conclusions}

Mezzanine financing instruments represent such a specific financing tool that, as the paper implies, assessment of their financial benefits requires modification of the assessment procedures used for assessment of the classic financing sources. Therefore, the hypothesis defined in the beginning has been proven. On the basis of this fact, methodology of assessment of the financial benefits of two selected mezzanine financing instruments, i.e. subordinated loans and convertible bonds was subsequently proposed on the principle of the cost intensity taking account of the time value of money. It is necessary to point out the fact that the cost intensity represents only one of a number of criteria that have to be taken into account when considering their utilization. When assessing mezzanine financing instruments, it is always also necessary to take account of other significant facts relating to their characteristics.

In conclusion, it is necessary to state that the proposed procedure of assessment of the costs of mezzanine financing instruments has its limitations, as it does not take account of the influence of the factor of time on the value of repayments, and the comparison has to be based on the identical volume of debt. A limiting factor of the presented paper is then the fact that calculations specified in the case study provide the resulting values in a wide range of the amounts of individual cost items. The case study was created with the aim to give an illustrative example of application of the proposed methodology for determination of the costs of debt in selected financial instruments, and at the same time it is based on actual data of the monitored period in the Czech Republic. It is possible to assume that companies interested in these instruments will have access to the exact information about individual cost items (individually specified for the given economic entity and particular conditions), and the proposed formulas will make it possible for them to achieve precise results.

\section{Disclosure statement}

We do not have any competing financial, professional, or personal interests from other parties.

\section{References}

Anson, M. J. P.; Fabozzi, F. J.; Jones, F. J. 2010. The handbook of traditional and alternative investment vehicles: Investment characteristics and strategies. $1^{\text {st }}$ ed. Hoboken: John Wiley \& Sons. http://dx.doi.org/10.1002/9781118258248

Baker, H. K.; Filbeck, G. 2013. Alternative investments: Instruments, performance, benchmarks and strategies. $1^{\text {st }}$ ed. Hoboken: John Wiley \& Sons. http://dx.doi.org/10.1002/9781118656501

Baker, H. K.; Martin, G. S. 2011. Capital structure and corporate financing decisions: Theory, evidence, and practice. $1^{\text {st }}$ ed. Hoboken: John Wiley \& Sons. http://dx.doi.org/10.1002/9781118266250

Central Securities Depository Prague. 2013. Schedule of charges of the Central Securities Depository Prague [online], [cited 20 September 2013]. Available from Internet: http://www.centraldepository.cz/images/dokumenty/cenik_cdcp/CDCP_Cenik_01042013.pdf

CMGDB. 2007. Programme "Progress" [online], [cited 5 December 2013]. Available from Internet: http://www.cmzrb.cz/NR/rdonlyres/5FF83F43-EF39 -45B0-8268-0B453687C805/1821/Progres.pdf 
CNB. 2015. CNB Lombard rate [online], [cited 5 May 2015]. Available from Internet:

http://www.cnb.cz/cs/faq/jak_se_vyvijela_lombardni_sazba_cnb.html

CNB. 2013. Methodology [online], [cited 15 July 2013]. Available from Internet: http://www.cnb.cz/cs/dohled financni trh/ souhrnne informace fin trhy/zakladni_ukazatele fin trhu/banky/bs ukazatele metodika.html

CNB 2010. CNB new inflation target [online], [cited 10 September 2014]. Available from Internet: http:/www.cnb.cz/miranda2/export/sites/ www.cnb.cz/cs/menova_politika/strategicke_dokumenty/download/inflacni_cil_cnb_2010.pdf

European Commission. 2010. Mezzanine finance: Final report [online], [cited 7 December 2010]. Available from Internet: http://ec.europa.eu/enterprise/newsroom/f/document.cfm?action=display\&doc_id= $1065 \&$ userservice _id=

Eurostat. 2010. European System of Accounts - ESA 2010 [online], [cited 3 November 2013]. Available from Internet: http://www.lb.lt/n22873/esa_2010-en_book.pdf

Fotr, J.; Soucek, I. 2011. Investment decision making and project management. $1^{\text {st }}$ ed. Prague: Grada Publishing.

Hobza, A. 2009. The European Union and economic reforms. $1^{\text {st }}$ ed. Prague: C. H. Beck.

Hucka, M.; Kislingerova, E.; Maly, M. 2011. Trends of large enterprises: Enterprises in the 21 st century. $1^{\text {st }}$ ed. Prague: C. H. Beck.

Kislingerova, E., et al. 2007. Managerial finance. $2^{\text {nd }}$ ed. Prague: C. H. Beck.

Meluzin, T.; Zinecker, M. 2009. IPO - the initial public offering as a source of financing of business development. $1^{\text {st }}$ ed. Brno: Computer Press.

Oswald, E. 1994. Obligace alternativní zdroj financování, Ekonom 38(8): 31-35.

Pratt, S. P.; Grabowski, R. J. 2014. Cost of capital: Applications and examples. $5^{\text {th }}$ ed. Hoboken: John Wiley \& Sons.

http://dx.doi.org/10.1002/9781118846780
Silbernagel, C.; Vaitkunas, D. 2010. Mezzanine finance [online], [cited 10 October 2011]. Available from Internet: http://pages.stern.nyu.edu/ igiddy/articles/Mezzanine_Finance_Explained.pdf

Svedik, J.; Tetrevova, L. 2015. Use of public debt mezzanine instruments in the Czech Republic, Procedia - Social and Behavioral Sciences 210(2): 449-455. http://dx.doi.org/10.1016/j.sbspro.2015.11.393

Svedik, J.; Tetrevova, L. 2014. Mezzanine financing instruments as alternative sources of financing industrial enterprises, in $23_{r d}$ International Conference on Metallurgy and Materials "METAL 2014", $21-$ 23 May 2014, Brno, Czech Republic, 1908-1913.

Tetrevova, L. 2009. Mezzanine finance and corporate bonds, Finance: Challenges of the Future 8(9): $145-150$.

Tetrevova, L. 2006. Projects financing. $1^{\text {st }}$ ed. Prague: Professional Publishing.

Valach, J. 2005. Investment decision making and longterm financing. $2^{\text {nd }}$ ed. Prague: Ekopress.

Vasilescu, L. G.; Popa, A. 2006. Mezzanine finance - an alternative for the firms' financing, in International Scientific Conference "Competitiveness and Stability in the Knowledge-Based Economy”, 20-21 October 2006, Craiova, Romania, 424-432.

Vlckova, V.; Exnar, F.; Machac, O. 2012. Quantitative methods for support of managerial decision-making in logistics, in $7^{\text {th }}$ International Scientific Conference "Business and Management 2012", 10-11 May 2012, Vilnius, Lithuania, 1015-1022.

Vochozka, M. 2011. Methods of enterprises evaluation. $1^{\text {st }}$ ed. Prague: Grada Publishing.

Volkmann, C. K.; Tokarski, K. O.; Grünhagen, M. 2010. Entrepreneurship in a European perspective: Concepts for the creation and growth of new ventures. $1^{\text {st }}$ ed. Berlin: Gabler Verlag. http://dx.doi.org/10.1007/978-3-8349-8752-5

Welz, S. 2006. Mezzanine financing. $1^{\text {st }}$ ed. München: GRIN Verlag. 